\title{
Editorial
}

\section{Issues of management and monitoring by laboratory methods in respiratory medicine: editorial introduction}

\author{
Ezekiel Uba Nwose*
}

Department of Community Health, Charles Sturt University, Orange NSW 2800 Australia

Received: 14 April 2016

Accepted: 09 May 2016

*Correspondence:

Dr. Ezekiel Uba Nwose,

E-mail: nwoseeu@gmail.com

Copyright: (c) the author(s), publisher and licensee Medip Academy. This is an open-access article distributed under the terms of the Creative Commons Attribution Non-Commercial License, which permits unrestricted non-commercial use, distribution, and reproduction in any medium, provided the original work is properly cited.

There is a gap in knowledge, attitude and practice (KAP), as well as between findings of experimental versus clinical observational studies in respiratory diseases. Hence, research is on-going especially in disease management and monitoring by laboratory methods. A cursory review or passive discussion of laboratory services will reveal that the service and research provisions of Pathology are challenging in view of fiscal constraints and other competing forces.

While it is argued in the developed world that several laboratory tests are inappropriate and that over-diagnosis and over-treatment are large drivers of increase in healthcare cost, the opposite is arguably the case in lowmid income countries where basic facilities are unavailable for laboratory tests such as most laboratories lacking the resources to perform e.g. simple immunohistochemistry (IHC). ${ }^{1-3}$ The implication is that the concept of disease management and monitoring by laboratory methods is well acknowledged, but the practice is often shrouded in debate of to test or not to test. ${ }^{4}$

Unarguably, respiratory diseases encompass some of the communicable and non-communicable leading causes of death worldwide; while industrialization is enhancing the phenomenon of increased risk, especially in urban areas. ${ }^{7}$ Tobacco smoke remains a controversial subject, but also unarguably a risk factor. The need for clinical toxicity testing has been advocated, not-with-standing that haematological and haemorrheological changes possibly associated with cigarette smoking have long been speculated. ${ }^{8,9}$ In this special issue, the prospect of laboratory assessment of cigarette toxicity at the subclinical level i.e. prior to obvert manifestation of disease is one of the key themes and research data is presented to advance the usefulness of whole blood viscosity. The papers articulate the KAP of health professionals and highlights simple laboratory tests that are useful and potentially add little or no extra cost to the healthcare system.

There is knowledge of overlap or confusion between asthma and chronic obstructive diseases, as much as there is overlap between cardiovascular (CVD) and respiratory diseases. ${ }^{10-12}$ In this special issue, professional medical scientists; Phillip Bwititi and Kenneth Chinkwo with experience from three continents collaborate to discuss effects of obesity on inflammatory and oxidative stress markers in asthma' as well as a narrative review of current clinical practice on oxidative stress markers in infectious respiratory diseases.

Discussion of respiratory diseases and medicine is albeit incomplete without reference to infectious diseases such as tuberculosis and its management. Thus, biochemist and molecular microbiologist, Efe Aganbi, and medical practitioner, Innocent Onyia, have been invited on evaluation of acetylator phenotype of isoniazid among TB patients: update on management of toxicity. The paper includes previously unpublished original laboratory-based research and an update with a mini literature review. As yet, most pharmaceutical respiratory medicines interact with the cardiovascular physiology, especially through inflammation, oxidative stress and white blood cell responses, en route to cause or 
exacerbate CVD. The laboratory monitoring of efficacy and toxicity of pharmaceutical and complementary medicinal therapies are as yet clinical practice issues to review. Thus, other major sub-themes in this issue are asthma, oxidative stress, and pharmaceutical therapies. In particular, professional pharmacists, Kwang Yee and Julie Knoblich, give a critical review of the cardiovascular safety of new inhaled medications for asthma and COPD from the pharmacist perspective.

In summary, this special issue is a book in journal format put together by a network of various expert healthcare professionals. The articles draw from clinical practice as well as academic research experiences. It is my hope that clinical and diagnostic communities in routine and research work will find it useful.

\section{REFERENCES}

1. Swan N, Balendra J. Wasted. ABC News 24 28th Sep 2015; Available from [http://www.abc.net.au/ 4corners/ stories/ 2015/09/28/ 4318883.htm].

2. Nakhoul GN, Hickner J. Management of adults with acute streptococcal pharyngitis: minimal value for backup strep testing and overuse of antibiotics. J Gen Intern Med. 2013;28(6):830-4.

3. Naresh KN, Raphael M, Ayers L, Hurwitz N, Calbi $\mathrm{V}$, Rogena $\mathrm{E}$, et al. Lymphomas in sub-Saharan Africa--what can we learn and how can we help in improving diagnosis, managing patients and fostering translational research? Br J Haematol 2011; 154(6):696-703.

4. Henry JB. Clinical Diagnosis and Management by Laboratory Methods, 17th edn. Canada: WB Saunders Co. 2001.
5. Aminian O, Zeinodin H, Sadeghniiat-Haghighi K, Izadi N. Respiratory symptoms and pulmonary function tests among galvanized workers exposed to zinc oxide. J Res Health Sci. 2015;15(3):159-62.

6. Lai Z, Wang X, Tan H, Huang Y, Lu C. Analysis of pulmonary dysfunction of 1953 coal miners in Hunan Province. Zhong Nan Da Xue Xue Bao Yi Xue Ban. 2015;40(7):764-9.

7. Wong A, Marrie TJ, Garg S, Kellner JD, Tyrrell GJ. Welders are at increased risk for invasive pneumococcal disease. Int $\mathbf{J}$ Infect Dis. 2010;14(9):e796-9.

8. Thielen A, Klus H, Muller L. Tobacco smoke: unraveling a controversial subject. Exp Toxicol Pathol. 2008;60(2-3):141-56.

9. Galea G, Davidson RJ. Haematological and haemorheological changes associated with cigarette smoking. J Clin Pathol. 1985;38(9):978-84.

10. Kim SR, Rhee YK. Overlap Between Asthma and COPD: Where the Two Diseases Converge. Allergy, Asthma \& Immunology Research. 2010;2(4):209-14.

11. Lee R, McNicholas WT. Obstructive sleep apnea in chronic obstructive pulmonary disease patients. Curr Opin Pulm Med. 2011;17(2):79-83.

12. Minghelli B, Oliveira R, Nunes C. Association of obesity with chronic disease and musculoskeletal factors. Rev Assoc Med Bras. 2015;61(4):347-54.

Cite this article as: Nwose EU. Issues of management and monitoring by laboratory methods in respiratory medicine: editorial introduction. Int $\mathbf{J}$ Res Med Sci 2016;4:1783-4. 